\title{
Towards an inventory of the mycobiota of the Lapland State Nature Biosphere Reserve (Murmansk Region, North-West Russia)
}

\author{
Ludmila G. Isaeva ${ }^{1}$, Iuliia R. Khimich ${ }^{*}$, Ivan V. Zmitrovich ${ }^{2} \&$ Natalia G. Berlina $^{3}$ \\ ${ }^{1}$ Laboratory of Terrestrial Ecosystems, Institute of the Industrial Ecology Problems of the North of the Kola Science \\ Center, Russian Academy of Sciences, Academic Campus, 14a, Apatity, Murmansk Region, 184209, Russia. \\ E-mail: isaeva@inep.ksc.ru. .Corresponding author: ukhim@inbox.ru \\ ${ }^{2}$ Laboratory of Systematics and Geography of Fungi, Komarov Botanical Institute, Russian Academy of Sciences, \\ Professora Popova str. 2, 197376, St. Petersburg, Russia. E-mail: IZmitrovich@binran.ru \\ ${ }^{3}$ Lapland State Nature Biosphere Reserve, Zelenaia str. 8, Monchegorsk, Murmansk Region, 184506, Russia. \\ E-mail: n_berlina@laplandzap.ru
}

\begin{abstract}
The article presents data on new locations of 65 aphyllophoroid fungal species in the Lapland State Nature Biosphere Reserve, 17 of which were new findings for the reserve. Four species (Gloeocystidiellum convolvens, Piloderma byssinum, Pseudotomentella vepallidospora, Scytinostromella heterogenea) are new records for Murmansk Region.
\end{abstract}

Keywords: aphyllophoroid fungi, new records, distribution, Lapland State Nature Reserve, Murmansk Region

\section{INTRODUCTION}

The Lapland State Nature Biosphere Reserve (hereafter 'Reserve') is located in the central part of Murmansk Region, between $67^{\circ} 39^{\prime}-68^{\circ} 15^{\prime} \mathrm{N}$ and $31^{\circ} 10-32^{\circ} 45^{\prime} \mathrm{E}$ (Fig. 1). The protected area occupies $2784 \mathrm{~km}^{2}$ and is one of the largest protected areas in Europe. The landscape of the Reserve is very diverse and comprises mountains and elevated flat terrain (SemyonovTyan-Schanskiy, 1988). General survey of the geographical conditions of the Lapland State Nature Reserve is given in the paper about liverworts of the Reserve (Borovichev, 2014). According to Ahti et al. (1968), the Reserve is situated in the Northern boreal zone. All mountains carry distinguishable vertical vegetation belts with northern taiga covering the foothills. The forest zone in the foothills of Chuna-tunra rises up to $400 \mathrm{~m}$. The spruce, pine and birch are the dominant tree species in forests of the Reserve, with mix of aspen, alder, willow (Isaeva \& Kostina, 2012). Pine forests, mostly lichen pine forests, cover $30 \%$ of the forested area and largely experienced the impact of fires and logging. Spruce forests cover $46 \%$ of the forested area and consist of large blocks separated by mountain tundra and birch forests (Anonymus, 1972). Mature and overmature spruce stands of dwarf shrubs-and-moss type predominate. Birch forests with occasional spruces are distributed mainly along rivers and streams and occupy $23 \%$ of the forested area. In the Reserve, pristine and secondary forests are of interest for the study of biodiversity and, in particular, the biota of wood-decaying fungi.

The first data on wood-decaying fungi in the Reserve can be found in reports by Pushkina (1961, 1974). Subsequently, several species were mentioned in reports on forest pest research (Anonymus, 1979; Karpenko, 1983). An inventory of the mycobiota was started in the 1980s (Isaeva \& Berlina, 1992, 2002; Isaeva et al., 2012). 116 species of aphyllophoroid fungi are now known from the Lapland Reserve (Krutov et al., 2012).

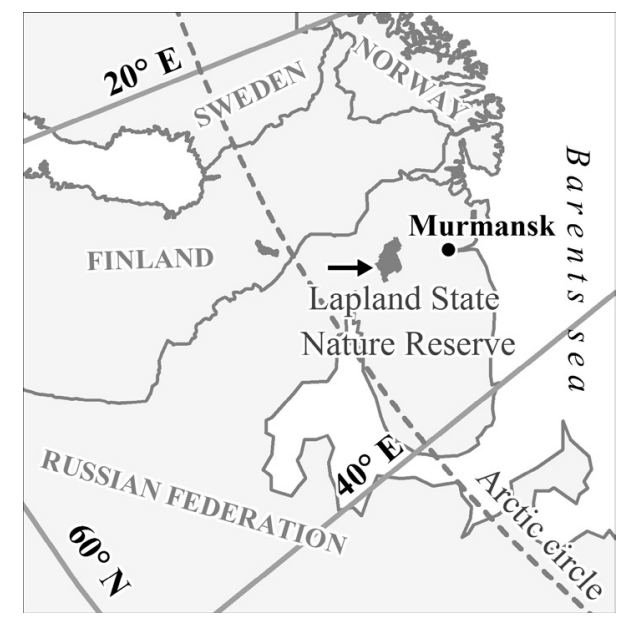

Fig. 1. The location of the Lapland State Nature Biosphere Reserve, Murmansk Region, Russia. 


\section{MATERIAL AND METHODS}

At the current stage of inventory of the Reserve's mycobiota, special emphasis was placed on the study of forests that have undergone natural and anthropogenic disturbances - windfalls, avalanches, etc.

The slopes of Chuna-tundra are rather gentle and avalanches occur more seldom than in Khibiny Mts, however, in early 1985, there was a registered avalanche on the south slope of Seydnotchorr Mt. The avalanche trail was about $100 \mathrm{~m}$ wide and several hundred metres long. The avalanche fell from the top edge of a steep slope at about $430 \mathrm{~m}$ and stopped on the rise in the dense spruce forest at about $200 \mathrm{~m}$. Not far from this area (approximately $1.5 \mathrm{~km}$ to the west) is situated the old bed of the avalanche presumed to have occurred in 1975 or 1976 . Young deciduous forest (birch, willow, rowan, alder) has formed over the last twenty-nine years. In 2011, this young forest on the slope and a forest on piedmont of Seydnotchorr Mt. were examined using conventional methods for mycological field work. Finds of fungi on woody debris at the foot of the mountain were considered separately, since it is difficult to discern the historical movements of such woody debris.

In spruce forests, windfalls are the main type of disturbance related to natural forest dynamics. Field work was carried out in 2012 in the native dwarf shrub-moss spruce forest (220-260 years old) at a site where there was a large windfall in 1989 or 1990 and in a pine stand in the midstream of Chuna River. When the Reserve temporarily was closed in the 1950s a pine forest was felled at the latter site and many wooden buildings were constructed (e.g. a sawmill, barracks, bakery, etc.). All the buildings are now destroyed. Their logs and planks, together with the dead trees of the surrounding pine forest were observed.

The present report is based on 106 samples of fungal fruitbodies, which are stored in the herbarium of the Institute of the Industrial Ecology Problems of the North KSC (INEP). Widespread species were recorded without collecting. For the species identification fruitbody samples were examined with microscopy and a standard set of chemicals (KOH, Melzer's reagent) (Kirk et al., 2008).
The taxa are arranged in alphabetical order. The names follow Index Fungorum (July 2014). An asterisk $\left({ }^{*}\right)$ means a new finding in the Lapland Reserve, a double asterisk $\left({ }^{* *}\right)$ - new finding for Murmansk Region.

Collecting localities: 1 - Seydnotchorr Mt., $67^{\circ} 41^{\prime} 30^{\prime \prime} \mathrm{N}, 32^{\circ} 25^{\prime} 44^{\prime \prime} \mathrm{E}$ : a - young deciduous forest, which was formed at the site of an avalanche in 1985; b - the slope and the foot of the mountain, shrub-moss spruce and sprucepine-shrub-moss forests, 17.08.2011; 2 - plot windfall from 1989-90, shrub-moss spruce forest (Chinglis Lake vicinity, 134 block, stratum 7), 6742'55,2”N, 32³3'25,5'E, 17.08.2012; $3 \mathrm{a}$ - area of destroyed wooden buildings, including old sawmill which existed in the 1950s, $67^{\circ} 45^{\prime} 06.5^{\prime \prime} \mathrm{N}, 32^{\circ} 11^{\prime} 03.3^{\prime \prime} \mathrm{E}$; $3 \mathrm{~b}$ - area of the hut "Squirrel's" (right bank of the Verchnyaya Chuna River), shrub-lichen-moss pine forest, 6745’”"N, 32¹0'54”E, 22-23.08.2012.

\section{ANNOTATED LIST OF SPECIES}

Alutaceodontia alutacea (Fr.) Hjortstam \& Ryvarden - 1b: on fallen trunk of spruce (INEP 1188, 1189).

AMPhinema BYssoides (Pers.) J. Erikss. - 1b: on fallen trunks of birch and aspen (INEP 1201, 1215); 2: logs of birch, on old fruiting body of Phellinus sp. (INEP 1102).

AMYLOCYSTIS LAPPONICA (Romell) Bondartsev \& Singer - 2: on fallen trunk of spruce (INEP 1107, 1112).

*Amylostereum chailletil (Pers.) Boidin - 2: on fallen trunk of spruce (INEP 1081).

*Antrodia albobrunnea (Romell) Ryvarden - 3a: on a pine board (INEP 1217).

Antrodia SERIALIS (Fr.) Donk - 1b, 2: on fallen trunk of spruce (INEP 1177); 3a: on a pine board (INEP 1223).

Antrodia sinuosa (Fr.) P. Karst. - 1b: on fallen trunk of spruce (INEP 1178).

ANTRODIA XANTHA (Fr.) Ryvarden - 1b: on fallen trunk of spruce (INEP1176); 3a: on boards of barrack (INEP 1224); 3b: on fallen trunk of pine.

*Antrodiella Pallasi Renvall, Johann. \& Stenlid - 2: on fallen trunk of spruce (INEP 1097-1101).

*APHANOBASIDIUM PSEUdotsugae (Burt) Boidin \& Gilles - 2: on fallen trunk of spruce (INEP 1084). 
Asterodon ferruginosus Pat. - 1b: on fallen trunk of spruce (INEP 1175); 2: on spruce stump and fallen trunk of birch (INEP 1089, 1090).

Botryobasidium VAGUM (Berk. \& M.A. Curtis) D.P. - 1b: on fallen trunk of spruce and birch (INEP 1165, 1166).

Ceraceomyces serpens (Tode) Ginns - 1a: on fallen trunk of birch (INEP 1184).

Chaetodermella luna (Romell ex D.P. Rogers \& H. S. Jacks.) Rauschert - 3a: on pine board (INEP 1218).

Chondrostereum purpureum (Pers.) Pouzar - 1a: on fallen branch of rowan (INEP 1208).

Coniophora Olivacea (Fr.) P. Karst. - 2: on fallen trunk of spruce (INEP 1082, 1083); 3a: on plywood (INEP1221); 3b: on fallen trunk of pine (INEP 1126).

CONIOPHORA PUTEANA (Schumach.) P. Karst. - 2: on fallen trunk of spruce (INEP 1106).

${ }^{*}$ Cytidia SALicina (Fr.) Burt - 3b: on fallen trunk of willow (INEP 1127).

DAEDALEOPSIS SEPTENTRIONALIS (P. Karst.) Niemelä - 2: on fallen trunk of birch (INEP 1088).

*Dichostereum BoREale (Pouzar) Ginns \& M.N.L. Lefebvre -2 : on fallen trunk of spruce (INEP 1084).

Fomes FOMENTARIUS (L.) Fr. - 1b: on fallen trunk of willow.

Fomitopsis Pinicola (Sw.) P. Karst. - 2: on fallen trunk of spruce.

Fomitopsis Rosea (Alb. \& Schwein.) P. Karst. - 1b, 2, 3b: on fallen trunk of spruce.

**Gloeocystidiellum convolvens (P. Karst.) Donk - 1a: on fallen trunk of birch (INEP 1212).

Gloeophyllum PROTRACTUM (Fr.) Imaz. - 3a: on pine logs of destroyed barracks.

Gloeophyllum SEPIARIUM (Wulfen) P. Karst. - 1b, 2: on fallen trunk of spruce.

HETEROBASIDION PARVIPORUM Niemelä \& Korhonen - 2: on fallen trunk of spruce (INEP 1105).

Hymenochaete cinnamomea (Pers.) Bres. - 1a: on fallen trunk of birch, alder and willow (INEP 1169-1171).

HyPHODONTIA ASPERA (Fr.) J. Erikss. - 1b: on fallen trunk of spruce (INEP 1187).

HyPHODONTIA BREVISETA (P. Karst.) J. Erikss. - 1a: on fallen trunk of birch (INEP 1190); 2: on fallen trunk of spruce (INEP 1109, 1110); $3 \mathrm{~b}$ : on fallen trunk of spruce (INEP 1125).

Hypochnicium вombycinum (Sommerf.) J. Erikss. - 1a: on fallen trunk of rowan (INEP 1186).
*IrPex lacteus (Fr.) Fr. - 3b: on fallen trunk of birch (INEP 1124).

LAURILIA SULCATA (Burt) Pouzar - 2: on fallen trunk of spruce (INEP 1104).

LAXITEXTUM BICOLOR (Pers.) Lentz - 1b: on fallen trunk of birch and other deciduous trees (alder or rowan) (INEP 1182, 1183).

Merulius tremellosus Schrad. - 1a: on fallen trunk of birch (INEP 1209).

PENIOPHORELLA PRAETERMISSA (P. Karst.) K.H. Larss - 1b: on fallen trunk of spruce (INEP 1185).

Phanerochaete laevis (Fr.) J. Erikss. \& Ryvarden - 1a: on fallen trunks of willow, birch, and fruiting body of Hymenochaete cinnamomea (INEP 1167, 1168, 1179, 1180); 1b: on fallen trunk of spruce and deciduous trees (alder or rowan) (INEP 1173, 1181); 2: on fallen trunk of spruce (INEP 1134); 3a: on fallen trunks of birch (INEP 1128, 1129).

Phanerochaete sanguinea (Fr.) Pouzar - 3b: on fallen trunk of pine (INEP 1132, 1225).

PHANEROCHAETE SORDIDA (P. Karst.) J. Erikss. \& Ryvarden - 1a: on fallen trunk and standing dead trees of birch and on fallen trunk of willow (INEP 1205, 1206, 1211); 3a, b: on pine logs; on fallen trunk of birch (INEP 1123, 1133).

Phellinus chrysoloma (Fr.) Donk $-1 \mathrm{~b}, 2$ : on fallen trunk of spruce.

Phellinus IGNiariUs (L.) Quél. - 3b: on standing dead trees of birch.

Phellinus laevigatus (P. Karst.) Bourdot \& Galzin - 1b: on fallen trunk of birch (INEP 1207).

Phellinus viticola (Schwein.) Donk - 1a, 2: on fallen trunk of spruce (INEP 1108, 1173).

Phellopilus nigrolimitatus (Romell) Niemelä, T. Wagner \& M. Fisch. - 2: on fallen trunk of spruce (INEP 1113, 1114).

Phlebia MELlea Overh. - 3a: on fallen trunk of pine (INEP 1122).

**Piloderma byssinum (P. Karst.) Jülich -2 : on fallen trunk of spruce (INEP 1095,1096).

Piloderma Bicolor (Peck) Jülich - 1b: on fallen trunk of alder (INEP 1202).

Postia CAESIA (Schrad.) P. Karst. - 2: on spruce column (INEP 1103).

**Pseudotomentella Vepallidospora M. J. Larsen - 2: on fallen trunk of birch (INEP 1092).

*Resinicium furfuraceum (Bres.) Parmasto - 1b: on fallen trunk of pine (INEP 1210); 3a: on pine boards and plywood (INEP 1118, 1119, 1222). 
*Scopuloides Rimosa (Cooke) Jülich - 1b: on fallen trunk of birch (INEP 1214).

** Scytinostromella HeTEROGENEa (Bourdot \& Galzin) Parmasto - 2: on fallen trunk of spruce (INEP 1091).

*Sistotremastrum Suecicum Litsch. ex J. Erikss. - 3a: on pine boards (INEP 1117, 1219).

Stereum hirsutum (Willd.) Pers. - 3a: on fallen trunk of birch (INEP 1130, 1131).

Stereum SANGUinolentum (Alb. \& Schwein .) Fr. - 1b: on fallen trunk of spruce (INEP 1203).

*Tomentella cinereoumbrina (Bres.) Stalpers 1b: on fallen trunk of birch (INEP 1216).

*Tomentella Ellisi (Sacc.) Jülich \& Stalpers 3a: on pine board (INEP 1120); 3b: on fallen trunk of willow (INEP 1121).

TRAMETES OCHRACEA (Pers.) Gilb. \& Ryvarden - 1b: on fallen trunk of birch.

*TRECHISPORA MICROSPORA (P. Karst.) Liberta - 2: on fallen trunk of birch (INEP 1094).

TRICHAPTUM ABIETINUM (Dicks.) Ryvarden - 3b: on fallen trunk of pine.

TRICHAPTUM FUSCOVIOLACEUM (Ehrenb.) Ryvarden - 3b: on fallen trunk of pine.

TRICHAPTUM LARICINUM (P. Karst.) Ryvarden - 2: on fallen trunk of spruce (INEP 1111).

TYRomyces Chioneus (Fr.) P. Karst. $-1 \mathrm{~b}$ : on fallen trunk of birch and other deciduous trees (alder and willow) (INEP 1200, 1213).

Veluticeps abietina (Pers.) Hjortstam \& Tellería - 1b, 2: on fallen trunk of spruce (INEP $1115,1204)$.

Xenasmatella vaga (Fr.) Stalpers - 1a: on fallen trunk of alder (INEP 1172); 2: on fallen trunk of birch and on fallen trunk of spruce (INEP 1086, 1087, 1093); 3a: on boards of burnt box (INEP 1220).

\section{RESULTS AND DISCUSSION}

In total, 65 species of aphyllophoroid fungi were recorded, of which four species (Gloeocystidiellum convolvens, Piloderma byssinum, Pseudotomentella vepallidospora, Scytinostromella heterogenea) are new for the Murmansk Region. Gloeocystidiellum convolvens and Scytinostromella heterogenea have been recorded in the taiga zone of Finland (Kotiranta et al., 2009). Piloderma byssinum is close to P. bicolor, although the latter is distinguished by the bright saffron-yellow colour of its basidiomes and silky mycelial cords. The ecology of these two species significantly overlaps. Piloderma byssinum has been found in the northern forests of Karelia and is fairly widespread in Finland (Kotiranta et al., 2009; Krutov et al., 2014), although it is less common than P. bicolor. Pseudotomentella vepallidospora is a very interesting find, previously known from North America and the Far East of Russia (Kõljalg, 1996) with a more recent record in Western Siberia (Filippova \& Zmitrovich, 2013). In Fennoscandia it is known from southern Sweden (Hansen \& Knudsen, 1997). Thus, our find is probably the northernmost in Europe and Russia.

Seventeen species are first recorded for the Reserve: Amylostereum chailletii, Antrodia albobrunnea, Antrodiella pallasii, Aphanobasidium pseudotsugae, Cytidia salicina, Dichostereum boreale, Gloeocystidiellum convolvens, Irpex lacteus, Piloderma byssinum, Pseudotomentella vepallidospora, Resinicium furfuraceum, Scopuloides rimosa, Scytinostromella heterogenea, Sistotremastrum suecicum, Tomentella cinereoumbrina, T. ellisii, Trechispora microspora. Of these, Tomentella cinereoumbrina was previously listed for Murmansk Region, but only as a literature record (Kõljalg, 1996).

Three studied localities revealed varying mycobiota. In the young deciduous forest developing in the aftermath of an avalanche, eleven species of wood-destroying fungi were recorded on the hardwood. Hymenochaete cinnamomea, Phanerochaete laevis and $\mathrm{Ph}$. sordida appeared as relatively common species.

The area subjected to wind damage in 1989 or 1990 differed from the other studied areas and had the largest number of new species for the Reserve; three of them (Piloderma byssinum, Pseudotomentella vepallidospora and Scytinostromella heterogenea) were new also for Murmansk Region.

In the old sawmill, eleven species of wooddecaying fungi (Antrodia albobrunnea, A. serialis, A. xantha, Chaetodermella luna, Coniophora olivacea, Gloeophyllum protractum, Phanerochaete sordida, Resinicium furfuraceum, Sistotremastrum suecicum, Tomentella ellisii, Xenasmatella vaga) were found on pine boards, plywood and logs. These species are widely distributed in pine forests. Chaetodermella luna, Resinicium furfuraceum and Tomentella ellisii were previously found on wooden boards (Khimich et al., 2015, in press). 


\section{ACKNOWLEDGEMENTS}

The administration of the Lapland State Nature Biosphere Reserve is thanked for their comprehensive assistance with organization of the field trip. Mr. A. Savchenko (Polar-alpine Botanical Garden-Institute of KSC RAS) is thanked for preparing the map. Thanks are also due to Dr. N. Koroleva and Dr. E. Borovichev for their valuable comments and improvements to the English of the manuscript.

\section{REFERENCES}

Ahti, T., Hämet-Ahti, L. \& Jalas J. 1968. Vegetation zones and their sections in northwestern Europe. Annales Botanici Fennici 5(3): 169-211.

Anonymus 1972. Project 'Main Directorate of hunting and nature reserves at the Council of Ministers of the RSFSR on the organization and development of forestry in Lapland State Reserve' 1971-72. (In Russian). Explanatory note, book 1. Leningrad. 310 pp.

Anonymus 1979. Annals of Nature 1979. (In Russian). Monchegorsk, pp. 52-55 (Manuscript Fund of Lapland State Biosphere Reserve).

Borovichev, E. A. 2014. Checklist of liverworts of the Lapland State Nature biosphere Reserve (Murmansk province, Russia). Folia Cryptogamica Estonica 51: 1-11. http://dx.doi.org/10.12697/ fce.2014.51.01

Filippova, N. V. \& Zmitrovich, I. V. 2013. Wood decay community of raised bogs in West Siberia. Environmental dynamics and global climate change 4(1, 7): 1-16.

Hansen, L. \& Knudsen, H. (eds) 1997. Nordic Macromycetes Vol. 3. Heterobasidioid, aphyllophoroid and gastromycetoid basidiomycetes. Copenhagen. $444 \mathrm{pp}$.

Karpenko, A. D. 1984. The impact of industrial pollution on spruce phytocenoses of the Kola Peninsula. (In Russian). Abstract of dissertation for the degree of Candidate of Sciences. Tartu. 23 pp.

Khimich Yu. R., Zmitrovich I. V., Ruokolainen A. V. 2015. Aphyllophoroid fungi of the "Pasvik" State Nature Reserve. (In Russian). Mikologiya i Fitopatologiya (in press).

Kirk, P. M., Cannon, P. F., Minter, D.W. \& Stalpers J.A. 2008. Ainsworth \& Bisby's dictionary of the fungi. 10th edition. Wallingford. $771 \mathrm{pp}$.
Kotiranta, H., Saarenoksa, R. \& Kytövuori I. 2009. Aphyllophoroid fungi of Finland. A check-list with ecology, distribution, and threat categories. Norrlinia 19: 1-223.

Krutov, V. I., Ruokolainen, A. V., Kotkova, V. M., Isaeva, L. G. \& Khimich, Yu. R. 2012. Aphyllophoroid fungi in Pas in the Russian part of the Fennoscandian Green Belt. (In Russian). Fungal Communities in Forest Ecosystems. Vol. 3. Moscow, Petrozavodsk, Karelian Research Centre of RAS. Pp. 117-146.

Krutov, V. I., Shubin, V. I., Predtechenskaya, O. O., Ruokolaynen, A. V., Kotkova, V. M., Polevoy, A. V., Khumala, A. E. \& Yakovlev, Ye. B. 2014. Fungi and insects - consorts of the forest trees in Karelia Respublic. (In Russian). Petrozavodsk, Karelian Research Centre of RAS. 216 pp.

Kõljalg, U. 1996. Tomentella (Basidiomycota) and related genera in Temperate Eurasia. Oslo. 213 pp.

Isaeva, L. G. \& Berlina, N. G. 1992. To the flora and ecology of aphyllophoraceous fungi on Lapland Reserve. (In Russian). Proceedings of All-Union Conference: Ecology and fruiting macromycetessimbiotrofov of woody plants. Petrozavodsk. Pp. 33-34.

Isaeva, L. G. \& Berlina, N. G. 2002. Aphyllophoraceous fungi of Lapland Biosphere Reserve. (In Russian). Proceedings of the 5th International Conference: Problems of forest phytopatology and mycology. Moscow. Pp. 112-117.

Isaeva, L. G., Berlina, N. G. \& Khimich, Iu. R. 2012. Aphyllophoroid fungi of Lapland Reserve (in Russian). Proceedings of Lapland State Nature Biosphere Reserve. Moscow. Pp. 215-239.

Isaeva, L. G. \& Kostina, V. A. 2012. Forests of Reserve. (In Russian). Proceedings of Lapland State Nature Biosphere Reserve. Moscow. Pp. 69-111.

Pushkina, N. M. 1961. Species composition and characteristics of mushrooms fruiting bodies. (In Russian). 70 pp. (Manuscript Fund of Lapland State Biosphere Reserve).

Pushkina, N. M. 1974. Mushrooms - components of forest communities in the Lapland Reserve. (In Russian). Monchegorsk. 172 pp. (Manuscript Fund of Lapland State Biosphere Reserve).

Semyonov-Tyan-Schanskiy, O. I. 1988. The Lapland Reserve. (In Russian). Reserves of the USSR. Reserves of the European part of the RSFSR. Part I. Moscow. Pp. 61-89. 
34 Folia Cryptog. Estonica 